\title{
Business ethics from the standpoint of redemption: Adorno on the Possibility of Good Work
}

Article

Accepted Version

Reeves, C. and Sinnicks, M. (2021) Business ethics from the standpoint of redemption: Adorno on the Possibility of Good Work. Business Ethics Quarterly, 31 (4). pp. 500-523. ISSN 2153-3326 doi: https://doi.org/10.1017/beq.2020.45 Available at https://centaur.reading.ac.uk/98452/

It is advisable to refer to the publisher's version if you intend to cite from the work. See Guidance on citing.

To link to this article DOI: http://dx.doi.org/10.1017/beq.2020.45

Publisher: Cambridge University Press

All outputs in CentAUR are protected by Intellectual Property Rights law, including copyright law. Copyright and IPR is retained by the creators or other copyright holders. Terms and conditions for use of this material are defined in the End User Agreement.

www.reading.ac.uk/centaur 
Central Archive at the University of Reading

Reading's research outputs online 
Authors' version. Please see https://doi.org/10.1017/beq.2020.45 for the version of record, published in Business Ethics Quarterly.

\title{
Business Ethics from the Standpoint of Redemption: Adorno on the Possibility of Good Work
}

Craig Reeves \& Matthew Sinnicks

\begin{abstract}
Given his view that the modern world is 'radically evil', Adorno is an unlikely contributor to business ethics. Despite this, we argue that his work has a number of provocative implications for the field that warrant wider attention. Adorno regards our social world as damaged, unfree, and false and we draw on this critique to outline why the achievement of good work is so rare in contemporary society, focusing in particular on the ethical demands of roles and the ideological nature of management's self-understanding. Nevertheless, we show that Adorno's comments on activities such as art and philosophy mean that it is possible to draw on his work in a way that contributes constructively to the conversation about good and meaningful work within business ethics.
\end{abstract}

The only philosophy which can be responsibly practiced in face of despair is the attempt to contemplate all things as they would present themselves from the standpoint of redemption... all else is reconstruction, mere technique. (Adorno, 2005a: 247)

The modern social world is "radically evil" (Adorno, 1973a': 243), a fundamentally "wrong life" that "cannot be lived rightly" (Adorno, 2005a $\left.\mathrm{a}^{2}: 39\right)$. Such are the defining ethical claims of Theodor Adorno (1903-1969), the leading philosopher of the first generation of the Frankfurt School tradition (for engaging histories, see Jeffries, 2016; and Wiggerhaus, 1994). Such claims are, of course, starkly at odds with the basic commitments that define the field of business ethics - a field which typically presupposes not only that contemporary society is not 'radically evil', but that it is perfectly possible to flourish, act rightly, and prosper within corporate modernity.

It is no wonder, then, that while the later, more affirmative or reconstructive representatives of the Frankfurt School, such as Habermas (see Scherer \& Palazzo, 2007; Goodman \& Arenas, 2015; Scherer, 2015) and Honneth (see Islam, 2012; Visser, 2019), have had an impact in the business ethics literature, Adorno's thought has so far received virtually no attention whatsoever.

Nevertheless, we argue here that Adorno's thought is - despite first impressions - rich with insights for business ethics. Of course, no credible interpretation of Adorno could

1 Originally published 1966.

2 Originally published 1951. 
domesticate him as a friend of business. Indeed, in diagnosing our social world as radically evil, Adorno is indicting not just the contingent messy realities of our societies, but their basic institutional structure - including market civil society and the domain of business. And he maintains that the problems with our basic institutions are not such as could be overcome through incremental tweaks, legislative reforms, or well-meaning individuals doing their best. Rather, Adorno holds, our societies and their basic institutions are fundamentally and essentially bad.

Despite this, Adorno's ethical thought is by no means practically inert. Even though Adorno dismisses the modern social world's claim to provide an adequate context in which human beings could flourish, he takes seriously our need for ethical orientation in this compromised world. Moreover, he holds that while our social world is radically compromised, there are nevertheless significant differentiations to be made, and meaningful, if profoundly circumscribed, choices available, within it. As such, while criticising the ethical inadequacies of our social world, his philosophy nevertheless offers guidance on how to live 'less wrongly', as Freyenhagen (2013) puts it, within that world.

In this vein, we claim not that Adorno himself would have been willing to enter into the debates we address here, but only that his work has interesting and provocative implications for a variety of topics in the ethics of business, work, and commercial life, focusing in particular on our pursuit of good work.

We begin by outlining Adorno's ethical thought, setting out his distinctively thoroughgoing ethical criticism of the modern social world. We then develop the implications of his overall analysis for the question of the barriers to our pursuit of good work: the way role identification shapes our orientation to work under contemporary capitalism, and in particular, the role of management and its self-understanding, which is divided between positivistic and humanistic conceptions. We then go on to address the question of good work directly, and to outline how Adorno's thought can guide our reflections on the nature and possibility of the best kinds of work for human beings.

Ultimately, while we may not persuade legions of converts to Adorno's cause, we hope to show that Adorno's critique of contemporary society promises to reward, and indeed demands, business ethicists' serious attention - that, at the very least, it presents an instructive challenge worthy of their engagement. If our account is correct, it also offers something for Critical Theory scholars: insofar as our elaboration of Adorno's position offers genuine illumination of issues in business ethics, it fleshes out and offers justificatory support to Adorno's position. This suggests, in turn, that more sustained attention to business ethics will be fruitful for Critical Theory.

\section{ETHICS IN WRONG LIFE}

Adorno's thought was decisively coloured by an unholy historical trinity: the Gulag, Hollywood, and, above all, Auschwitz. A socialist, Jewish, modernist intellectual - whose 
hopes for the revolution were dashed in the East, who had fled the Nazi horror while close friends like Benjamin were not so fortunate, and whose experience as a refugee in American consumer capitalism was one of cultural trauma - Adorno's thought was forged in the shadow of (as he saw it) the Enlightenment project's disintegration (see Jager, 2003; Muller-Doohm, 2003).

The dominant theme of Adorno's thought thus became a melancholy protest against what he saw as the tragic privation of the modern social world. This social world is 'damaged' (Adorno, 2005a) in that it is a radically inhospitable place for human beings as such: it is antithetical to human flourishing and freedom. And this means modern society is inadequate in itself - it is a privative form of life. Adorno conceives of modern society as a "complex self-conditioning functional context" akin to a self-preserving system (Adorno, 2017a $\mathrm{a}^{3}$ : 147), whose distinctive mechanism of self-preservation is the market system guided by the profit motive (Adorno, 2008 ${ }^{4}$ : 9). The problem is that this system proceeds without regard to any values other than money value. The privilege of the profit motive means that the aim of maximizing money value is pursued, increasingly, at the expense of the very human interests the market was supposed to further. ${ }^{5}$

The organising principle of this system is the "universal exchange relationship in which everything that exists, exists only for something else" (Adorno, 19936: 26, emphasis added). This system is premised on commodity exchange, which deals with everything as an exchangeable unit. It permits particular things and people to show up only insofar as they are functionally reduced to - treated as if they were - quantities of the abstract quality of value. This makes human beings and their needs "seem like mere things obeying the laws of the marketplace" (Zuidervaart, 1991: 76). Particulars are viewed exclusively from the perspective of what other actors will see them as equivalent to. Hence, "in the developed bourgeois society all life is dominated by the principle of exchange," (Adorno, $2006^{7}: 50$ ) which, according to Adorno, constitutes the normative deep structure of modern societies.

In this "exchange society" (Adorno, 1993: 28), everything and everyone is functionally reduced to a means to something else for which it can be exchanged. People are assimilated to the economic roles of buyer and seller, and these roles functionally reduce people to quantities: the individual appears as a consumer (a quantity of buying-power) and a worker (a quantity of labouring-power). To satisfy their basic needs, individuals are compelled to sell their labour. They have to make their life activity into a commodity, that is. an exchangeable unit. What labour as a commodity is exchangeable for is determined by what is profitable. But what happens to be profitable has no necessary connection with people's needs, because consumptive wants have proved themselves to be so susceptible to

3 Originally delivered as part of a 1958 lecture series.

4 Originally delivered as part of a 1965/66 lecture series.

5 The tendency that Habermas (1987) would later describe as the colonization of the lifeworld by mediasteered systems.

6 Originally published 1963.

7 Originally delivered as part of a 1964/65 lecture series. 
manipulation and manufacture (for illuminating discussions of manipulative advertising, see Aylsworth, 2020; Lippke, 1999).

The exchange principle does not, however, remain within the economic sphere. The form of abstractive rationality underlying exchange, which treats every particular as an interchangeable unit and privileges systemic efficiency while suppressing real human interests, is equally evident in other social systems, such as the bureaucratic-administrative rationality that is increasingly subsuming social life. This underlying rationality is, according to Adorno, an outgrowth of a basic drive in the subject to master or dominate the object, "which finds its mental reflex in the principle of identity... the intrinsic aspiration of all mind to turn every alterity... into something like itself and in this way to draw it into its sphere." (Adorno, 2008: 9, emphasis added) By assimilating objects - including persons - to abstract categories and dismissing any remainder, the subject enhances his or her power to classify, predict, manipulate, and control them.

Most generally, such 'identity thinking' is the tendency to absolutize a formal principle, a concept, and treat particulars as merely bundles of the abstract qualities according to which they have been conceptualized. It is the thinking subject's unconsciously motivated propensity to forget that "the concept is always less than what is subsumed under it." (Adorno, 2008: 7) What gets overlooked is the "surplus of nonidentity" (Adorno, 1973a: 183), the concrete specificity of the particular object that Adorno construes as the natural or material moment, which feels to the thinking subject "like an absolute threat." (1973a: 183) Such thinking suppresses the "preponderance of the object" in its natural, material particularly (Adorno, 1973a: 183; see O’Connor, 2004: ch.2), saying "what something comes under, what it exemplifies or represents, and what, accordingly, it is not itself." (Adorno, 1973a: 149)

Put into practice in societally actual rationality, the results are ethically disastrous, for the identitarian tendency to assimilate particulars to general categories suppresses the concrete significance and specific worth of particular persons, their needs and activities, flourishing and ailing. If other people show up only as exchangeable units of fungible matter within a conflict-based practical system, the temptation will be to 'reify' them (Adorno, 1973a: 190) - to treat them as insignificant things to be mastered, manipulated and controlled, without having to encounter them as concrete, uniquely significant particulars (see Jutten, 2010).

This reification contributes to the sense in which modern society is 'unfree' (Adorno, 2006: 202-3) in that it undermines and frustrates individual autonomy. At one level, it prevents individuals from exercising anything like self-governing control over their lives, subverting what liberal political philosophy calls personal autonomy (see Raz 1986). That is, it subverts one's self-determination of one's life's course according to ends one sets for oneself. It does this, in particular, by forcing individuals to devote most of their time and energy to heteronomous rather than autonomous activities - modern work and the defences needed to tolerate it - and thereby draining people's energy and suppressing their creative capacities for spontaneity and self-determination. 
But the heteronomy - alien- rather than self-determination - runs deeper. Adorno conceives the individual not as independently constituted but as mediated by the social whole: "What presents itself as an original entity, a monad, is only the result of a social division of a social process. Precisely as an absolute, the individual is a mere reflection of property relations" (Adorno, 2005a: 153). That is, the individual's character is entwined with the character of the social world, through the adaptive processes of internalization and identification. Hence "freedom is really delimited by society, not only from outside but in itself..." (Adorno, 1973a: 297), so that "whether the subject is autonomous in reality... depends on objective reality" (Adorno, 2006: 222). And in actuality, Adorno claims, our damaged social world "prescribes his action to every individual, bar none" (1973a: 298), so that "in our universal state of dependency, there is no freedom" (Adorno, 2000: 176; see Reeves 2016a).

By and large, people have adapted to the world so deeply, and are so defended against the conflict and sacrifice this has involved, that they have had to forgo developing the rational capacities required either to autonomously encounter one's own psychic reality or to respond to social reality. Having internalized identity thinking, their experience of self and world is conditioned by distorting patterns of thought and action. We find ourselves vigilantly monitoring our every impulse under the watchful eye of the 'omnipresent executive' (Adorno, 2005a: 23), the imagined guardian of corporate expectations that so thoroughly governs our subjective experience. As a result of this distortion, our defences "absorb an immense quantity of available human strength" (Adorno, 1973a: 298), leaving little energy for autonomous, critical experience and practice.

Individuals do of course sometimes feel free from society, but that feeling itself often manifests the societal principle of domination at work in the individual: "Even where men are most likely to feel free from society, in the strength of their ego, they are society's agents at the same time. The ego principle is implanted in them by society." (Adorno, 1973a: 297) Even opposing the world can - where it takes the form of dogmatic selfassertion - be heteronomous.

Fundamentally, the inwardization of identity thinking generates heteronomy because it subverts the individual's potential for rational health (see Harcourt 2018). In particular, the coldness to one's own needs and suffering that it involves, along with the societal coldness towards others which it reinforces, undermines individuals' capacities for autonomous, rational experience and action. This is in no small part why our wrong life cannot be lived rightly.

That is, insofar as they have internalized identity thinking, individuals become trapped in a distorting pattern of thinking that prevents them from seeing or being guided by normatively relevant aspects of others and of themselves. And in that case, they can neither think nor act autonomously. Their coldness to their own and others' needs and suffering is the decisive moment because, Adorno argues, suffering has a sui generis normative significance that is the ultimate ground of genuine, autonomous experience (see Geuss, 2005; Baeza, 2015). It is reason's non-defensive integration of the impulsive, somatic 
"sense of solidarity with what Brecht called 'tormentable bodies"” (Adorno, 1973a: 286) both in oneself and in others - that would be required for autonomous experience. So long as individuals are defended against experiencing their own or others' suffering as in-itself significant, the power for autonomous resistance to a cold world will remain unlikely.

This is not to say that no freedom is available, however. Alongside his bleak diagnosis of the prevailing unfreedom of modern life, Adorno maintains that "despite all that, there is a genuine possibility of freedom." (2006: 265) It may be impossible to live a genuinely autonomous life in our damaged social world, but the chance remains to develop, with luck and effort, enough strength to resist the badness of that world.

However, even this possibility is limited by the fact that, as Adorno sees it, our societies are 'false' (2005a: 50) in that they necessarily present themselves falsely - that is, they functionally depend on ideology, on "socially necessary illusion." (Adorno, 2006: 118) Such illusions are necessary for the social whole because they are needed to assist individuals in rationalising their adaptation to it.

The essential implicit claim of such illusions is an extrapolation of identity thinking: that as things - society, people - are now is how they must be and ought to be (see Cook 2001); that the way things go is how they should go so that what exists is necessarily legitimate; that to challenge how things are is thus naive and impotent, while the realistic attitude is to accept and adapt to the world rather than complaining, and to go along with the prevailing identity principle and try to manipulate and control others. Such illusions deny that "what is [is] changeable." (Adorno, 1973a: 398) While such illusions are appearances, they are appearances that are necessary. As Adorno puts it, "it lies in the nature of society to produce the contents of the minds of human beings, [and] to ensure that they are blind to the fact that they mistake what is mediated and determined for actuality or the property of their freedom, and treat them as absolutes." (Adorno, 2008: 100) That is, such illusions are not arbitrarily manufactured ideas but the real semblance of damaged societies. Adorno devoted considerable energy to unpicking the ideological aspects of the major modern philosophical, sociological, and psychological theories. For in such works, he presses, the "formal categories are filled with a sedimented content that conceals the dominant [social] relations and the dominance of the universal." (2006: 32)

A central case of such identitarian ideology is positivism (Adorno, $1976^{8}$ ). Originating in early modern empiricism, its core implicit commitments are, firstly, that the most basic level of reality consists of states and events and the constant conjunctions or universal regularities that hold between them, and, secondly, that knowledge consists in the observation of states and events and the systematic organization of those observations by the hierarchical arrangement of formal, if-then generalizations - laws - from which those observations are deducible (e.g. Hempel and Oppenheim, 1948; Popper, 2002). In reducing the world to the determinations of universal empirical regularity, positivism suppresses

8 Originally published 1969. 
both the specificity of particulars, and the significance of real but unactualized potential and so the possibility of genuine change. (Adorno, 1973a: 248, 269; see Reeves, 2009a)

In the realm of human sciences, the aim is assumed to be the accumulation and organization of law-like statements covering the existing state of things, which can then be used to manipulate the human world in the manner of a 'social engineer' (see Neurath, 1973). Thus, positivistic ways of thinking tacitly invite and reinforce the assumption that the ways social and psychological reality are in the modern world are the only ways they could or ought to be, and are thus to be accepted rather than questioned. A human science

which is committed to the 'positive' is in danger of losing all critical consciousness whatsoever. Then anything that diverges from the positive, that urges... questioning the legitimation of the social instead of merely ascertaining and classifying it, becomes open to suspicion... Only a critical spirit can make science more than a mere duplication of reality by means of thought. (Adorno, 1973b9 : 11)

This attitude tends to generate a de-historicized, reductive and "reified consciousness" of human phenomena. (Adorno, 2005 $\mathrm{c}^{10}: 38$ ) Research informed by positivism is thus likely to be seriously deficient - tacitly affirming the damaged social world and concealing or diverting reflection on its systemic privations.

As against positivism, however, an opposed form of theoretical ideology is prominent: idealism or humanism. Whereas positivism implies that what happens to be the case is all there is, idealism or humanism insists on something more beyond the positivistic picture, on an ethical surplus. Yet it does so in such a way that this ethical surplus is internally compromised by its being shackled negatively to the positivistic world to which it is opposed: by its being posited either as already available or as belonging to an extraempirical beyond, or both. We explore these ideologies with reference to management's self-understanding in the following section.

Such theoretical ideologies infiltrate ordinary consciousness primarily via 'the culture industry'. ${ }^{11}$ But, Adorno insists, the culture industry is not perfectly efficient, and the societal integration of the individual is not total. Something survives in the individual that resists it: "It is doubtful that the culture industry and the consciousness of its consumers make an absolutely symmetric equation" (Adorno, 2005b: 174), because "the real interests of individuals are still strong enough to resist, up to a point, their total appropriation" (Adorno, 2005b: 175). This is not the least of the reasons why critical theoretical scrutiny of the damaged social world remains worthwhile.

Adorno, then, offers an ethical critique of modern social life that has been overlooked in business ethics and yet is philosophically distinctive and, we suggest, rich in insight. Its

9 Originally published 1972.

10 In Critical Models, originally published 1969.

11 Today there can be no mistake that a positivistic attitude has filtered through from the theoretical sphere into the realm of the culture industry, of which the algorithmic machinations of online platforms are the latest development. 
dominant normative register is that of badness rather than injustice, say, so that his social criticism is substantive rather than formal (see Freyenhagen, 2018). He is concerned not with unfairness but with what society does to and makes of people - the extent to which it suppresses individuals' flourishing and freedom. And his critical ethics thus has a naturalistic Aristotelian conception of goodness and badness - flourishing and ailing - in play.

Yet Adorno does not argue from a substantive account of flourishing, which he thinks remains unrealised and so unknowable. Adorno's is a radical and negative Aristotelianism (Freyenhagen, 2013: ch.9; Reeves, 2016b). He proceeds by diagnosing and explaining concrete instances of socially rooted ailing and privation, which he claims are objective ones that are validated not against subjects' self-understandings but by their conjunctive power to illuminate the phenomena of modern social experience. Indeed, Adorno claims that "the only thing that can perhaps be said is that the good life today would consist in resistance to forms of the bad life that have been seen through and critically dissected by the most progressive minds" $\left(2000^{12}: 167-8\right)$. In line with this, we proceed by focusing on a critique of aspects of the 'bad life' which constitute barriers to our pursuit of good work, before going on to address the possibility of such good work within capitalist society.

\section{WORK IN WRONG LIFE I: ROLE-IDENTIFICATION}

Work is, for most people, "time that is determined heteronomously" (Adorno, 2005b: 167), determined, that is, according to an end and a form which are alien to the agent. In the employment relationship, one takes on a role, and as such is constrained to prioritise the ends set by one's employer, for as long as one wishes to remain employed at least. In this way, the contemporary firm is often akin to an authoritarian state (Anderson, 2017). As Adorno puts it, there is a contradiction between "the definition which an individual knows as his own and his 'role', the definition forced upon him by society when he would make his living" (1973a: 152) - a contradiction, that is, between freedom and the necessity of getting by in a world hostile to one's real human needs.

Most are forced by market pressures to subordinate themselves to the alien direction of another, to rent themselves as economic mercenaries doing work that is entirely dissociated from their own 'intentions', and indeed even those intentions are liable to distortion by the process of their formation in market-society. Yet even those more fortunate in the labour market nevertheless remain on licence and always potentially hostage to the contingencies of market forces. In other words,

no-one, without exception, can now determine his own life within even a moderately comprehensive framework, as was possible earlier in the assessment of market relationships. In principle everyone, however powerful, is an object. (Adorno, 2005a: 37)

12 Originally delivered as part of a 1963 lecture series. 
Individuals' propensity to identify with the social conditions of their lives suggests a more radical and primordial moment of psychic violence in which the individual's inner needs are neutralised in advance. That is, people are prone to adaptively internalizing the principle of a harsh world so deeply that their suppressed needs no longer register. The needs themselves do not persist; they are distorted into the "wrong form", (Adorno, 1973a: 92) into "false" or "inverted needs" pre-emptively deformed so that they are compatible with an inhospitable world (Adorno, 1973a: 93; see Nevasto 2019). This, Adorno claims, helps explain why people so readily identify with heteronomous conditions rather than reacting to and resisting those conditions. And in adapting themselves to an inhospitable social world, they prevent themselves from being what they really are themselves, from encountering their real needs and interests.

This observation suggests an affinity between Adorno's position and more recent work on adaptive preferences. The concept of adaptive preferences has its origins in Elster's (1983) comments on unconscious preference formation but is more often associated with Nussbaum's (2001) normative application. Adaptive preferences, in the latter sense, are unconsciously motivated preferences for things which are not good for us, and which we should not prefer, other things being equal, such as being discriminated against or disrespected. As Satz notes, "markets themselves can help shape our preferences [and thus] they may not reflect what is really important for us" (Satz, 2010: 69). The difference is that for Adorno the scope of such adaptive preferences is wide, sometimes all-encompassing, and market-shaped preferences are often directly contrary to our real needs.

The phenomenon of role-identification is a telling example of this, and marks a servile subordination to the 'realities of work'. Adorno notes that

the growing concentration of the economy, the executive and the bureaucracy has advanced to such an extent that people are reduced more and more to the status of functions. What freedom remains is superficial, part of the cherished private life, and lacks substance as far as people's ability to determine their own lives is concerned. (Adorno, 2006: 5)

On this view, while the 'cherished private life' is conceptually distinguishable from the self that reflects one's work role, it is already subordinate to it. The private self is mutilated and already defined by its limited freedom and its inability to meaningfully determine its life, a determination that would require some control over one's daily activities, including those of the workplace.

The pressure toward identifying with the social world makes individuals prone to internalize their objectively imposed roles and to see themselves under alien concepts that are antagonistic to their real needs and potential for freedom. Hence, even in their private existence, freedom is suppressed - so much so that any straight-forward distinction "between human beings as they are in themselves and their so-called social roles" has become impossible (Adorno, 2005b: 167), for those

roles extend deep into the characteristics of people themselves, into their innermost composition. In the age of truly unprecedented social integration it is difficult to discern 
anything at all in people that might be other than functionally determined. (Adorno, 2005b:

$167-8)$

To cope with the demand to take up alien economic roles, individuals - Adorno suggests internalise those roles, which sediment into alien identities.

Now if Adorno is right, we would not expect phenomenological research into subjective experiences of work to be a reliable guide to the ethical problems of role-identification. Indeed, it is striking how often employees, even in the face of increased precarity and work intensity, retain 'personal attachments' to their employers and occupations (Musílek, Jamie, $\&$ McKie, 2020) even as the damage done by social reality renders them cold to their own needs.

This ostensibly puzzling attachment to one's employers manifests itself in the subjective enjoyment of forms of work that are transparently bad. Hughes (1951: 319) suggested that 'dirty work' carries a stigma or taint and, as a result, those who perform such jobs are also stigmatised. However, people who do such jobs are often quite satisfied by their work, with cleaners seeming to be particularly happy (see Léné, 2019). A partial explanation may be that such work involves relatively loose monitoring or an enhanced degree of camaraderie (see Deery, Kolar, \& Walsh, 2019), but this seems unlikely to be the whole story. Adorno's account would suggest a further explanation in terms of psychological self-preservation. It is not that the subjective experience of such work is directly a phenomenon to be welcomed; rather, it is that, shorn of any sense of power to change the situation, the only way for such persons to avoid despair is to reframe their situation as 'not all that bad', or 'quite pleasant really'.

On top of the inherent inadequacy of their work, workers who identify with inherently inadequate work flourish less, because in order to identify with their role, they must inevitably repress, split off, or dissociate their very dissatisfaction with their predicament. That is, they not only confront an external antagonism to their well-being, but they internalise that antagonism, identifying with it and taking it inside. Since they are unable to adjust the world to their own needs, they adapt their own needs to the world, disavowing their own dissatisfaction with their experience. Now they do not merely tolerate unsatisfying work, they embrace it. According to Adorno, the psychic costs of such identification are the disowning of one's apprehension of one's needs and suffering such that one's reflective self-awareness is aligned with the constraints of the identified-with role(s). Such role-identification amongst workers might, then, seem to be a prime example of the inwardization of identity thinking and its consequences.

Yet, far from being seen as a problem, there are currents in the literature that endorse conceiving of business ethics as a matter of teasing out the ethically salient nuances of the business role, and treating wider personal and ethical commitments as being quite irrelevant. Sternberg restricts business ethics to the ethical choices we face in our "business capacity" (2000: 252). Marcoux suggests that business ethics should be restricted to an examination of the "moral contours of business practice" (2009: 26). Heath's (2014) influential market failures approach to business ethics emphasises the function of the 
market and conceives of business ethics as a set of deontic constraints designed to uphold regulation and behaviour that are conducive to this function. Adorno's position presents a distinctive challenge to such accounts in pressing the freedom-undermining effect of the social pressure to adapt to and identify with employment roles.

His point is not merely that someone's freedom is constrained by the range of actually available roles. The individual is also pressed to internalize his or her transient and tentative relations to those roles, so that such transience and tentativeness becomes the very form of the person's relation to his or her identities. In this light it is perhaps no mere coincidence that sociology regularly refers to persons as social actors; the structure of economic roles demands of everyone that he or she live like an actor ready to take up any given role in order to make ends meet. The social demand to make oneself available to fill any role - to be an actor - pushes individual freedom back into the private sphere; one's freedom as a person is whittled down to the limited discretion one exercises over which economic roles one takes up and the hemmed-in freedom one exercises in one's private life. The fragmented role of the actor is perhaps becoming the social role par excellence, and given the increasing scope for monitoring and measurement available today, it seems that now there is rarely an opportunity for 'off-stage' repose.

Indeed, various digital transformations in the workplace in recent decades have "become entangled with societal developments, such as new forms of capitalism, new modes of production, the editing of social realities, and emergent forms of governance" (Flyverbom, Deibert, \& Matten, 2019: 8), which has opened up even greater possibilities for domination by roles. In a less wrong life, the "liberated ego, no longer locked up in its identity, would no longer be condemned to play roles either... society would lose the horror of shaping the individuals throughout" (Adorno, 1973a: 278-9) - but this must seem like a rather remote possibility today.

This sense of subordination to one's work role, or to one's actor role in juggling various roles, or a general tendency for loyalty to one's employer to be treated as meritorious (for discussions of this concept in the context of business ethics, see Melé, 2001; Varelius, 2009), has broader ethical implications for the self and the kinds of relationships available to us under capitalism. Adorno writes that

the private lives of countless people are becoming those of agents and go-betweens; indeed the entire private domain is being engulfed by a mysterious activity that bears all the features of commercial life without there being actually any business to transact... [Such people act so as to] ingratiate themselves with the executive they imagine omnipresent, and soon there is no relationship that is not seen as a 'connection', no impulse not first censored as to whether it deviates from the acceptable. (2005a: 23)

The upshot is that, whereas it was once considered "uncouth" to pursue practical aims in one's personal life, now "it is seen as arrogant, alien, and improper to engage in private activity without any evident ulterior motive. Not to be 'after' something is almost suspect" (2005a: 23-24). Adorno's words here are prescient. 


\section{WORK IN WRONG LIFE II: MANAGEMENT AND ITS SELF-UNDERSTANDING}

Such identification with bad work, internalization of personal subordination to one's work roles and to one's actor role, is promoted by certain managerial practices which deliberately encourage employees' attachment, and indeed personal subordination, to commercial life. Precarious contracts and various forms of employee monitoring have become normalised (Rubery, Grimshaw, Keizer, \& Johnson, 2018), and recruitment practices such as 'social media screening' of job candidates threatens to further cement the tendency to see every relationship as a contact, and every facet of one's personal life as a means to a 'practical', that is, economic, end.

Social media screening of applicants is a particularly illuminating example. It is becoming more widespread (Cunningham, 2013; Jeske \& Shultz, 2016) and is employed with the aim of gathering further information about candidates (Slovensky \& Ross, 2012), despite the fact that there is evidence that it is ineffective (Van Iddekinge, Lanivich, Roth, \& Junco, 2016). Tellingly, "many hiring professionals consider which groups [candidates] belong to and what others post to their profiles to be important reflections of a candidate." (Root \& McKay, 2014: 205) The corresponding need to maintain an 'on brand' social media presence suggests that Adorno's metaphorical 'omnipresent executive' is acquiring a literal actuality that Adorno could not have foreseen, fuelling a felt need for hypervigilance regarding one's social interactions that is deeply antithetical to human flourishing and freedom.

Another powerful barrier to the possibility of good work is managerial ideology. Management is an archetypal embodiment of the identitarian reason that, with its urge to classify and categorise human beings so that their behaviour might be predicted and controlled, Adorno locates as the dark side of Enlightenment. A significant strain in management research endorses a scientistic and technicist conception of management as essentially an art of classifying, appraising, and manipulating persons. As Freeman and Newkirk put it: "Implicit in much of the management discussion is a mechanical, deterministic, positivistic view of business - a financial engine controlled by the machinery of scientific management." (2009: 117)

Adorno's critique of positivism is readily applicable to this position. As we saw, according to Adorno positivism obscures the distinction between what is and what ought to be (Cook, 2001), a distinction that is largely missing from such research. ${ }^{13}$ It implicitly accepts the existing state of things and aspires to accumulate predictive knowledge of human beings so as to be able to manipulate and control them in the sense in which the natural sciences use knowledge of fixed tendencies and propensities to manipulate the natural world.

13 For this reason, Adorno's work has found some application in the field of critical management studies (examples include Parker, 2003; Klikauer, 2015). Convincing critiques of positivism abound (see Keat, 1981: ch.1; Sayer, 1992; Benton, 1977; Outhwaite, 1987: ch.1), and Adorno's work has been a decisive mainspring of this literature. 
The Adornian position here has strong affinities with Alasdair MacIntyre's well-known critique of management as being inherently manipulative and dependent on an illusory conception of managerial expertise (MacIntyre, 2007: ch.3; see Sinnicks, 2018). However, there is a rival conception of management that Adorno's ethics is also well-placed to critique. Whereas the technicist model of management is relatively unconcerned by the moral contours of the managerial role - on such a view, the manager is an expert who is relatively divorced from 'softer' questions of values - the humanistic understanding of management begins with the question: "[g]iven the role of the manager, what are the obligations and responsibilities that accompany that role?" (Bowie \& Werhane, 2004: 1)

Within business ethics this humanistic understanding of management is more widely accepted than is the positivistic or technicist understanding. As a result, much work in business ethics is concerned with such topics as the distinctive social and ethical responsibilities of management (Carroll, 2000; von Kriegstein, 2016), whether management is a profession (Donaldson, 2000), whether management is an intrinsically good and morally educative practice (Moore, 2008), which virtues the managerial role requires (Audi, 2012), whether management requires phronesis (Tsoukas, 2019), and so on.

However, by Adornian lights, well-meaning attempts to humanise management are, like the positivist-technicist accounts they oppose, 'false', an example of ideology, of socially necessary illusion. This is because they posit an ethical surplus which points beyond how things happen to be as already existing and thus as implicitly vindicating an evil social world, while blinding themselves to the truth of the positivistic picture, namely, that others are widely treated as mere tools to be mastered, manipulated, and controlled. Indeed, even research into ethical management adopts a presupposition of managerial superiority and underplays the capacities of ordinary employees (Munro \& Thanem, 2018).

On this view, attempts to cast management in humanistic terms are themselves acts of selfpreservation. It is difficult, if not impossible, for people to understand themselves as devoting so much of their time and energy merely to performing tasks required of them by capitalist society, and thus it may be better to understand managerial ethics as a form of what Sykes and Matza (1957) called 'techniques of neutralization'. Whereas rationalisations are used after the fact to insulate people from blame or self-approbation, techniques of neutralization can occur in advance of any questionable behaviour as a means of lessening the ostensible tension between that behaviour and other, countervailing expectations, values, or commitments. This can perhaps help us to explain the frustratingly cyclical nature of business ethics, noted by Abend (2013,2014), where periods of recurrent scandal are followed by periods in which all involved earnestly resolve never to let such failings occur again, before they inevitably do, and commentators are left puzzling over the frequently observed "gap between what businesses should be doing and what they actually do" (Brenkert, 2019: 918). In this way managers are victims of the general problem of roleidentification that leads to delusionally happy cleaners, even as they are one of its central enforcers. 
Most occupations presently available are artefacts of the capitalist system and thus are analogous to the entertainment products that are the outputs of the culture industry. A genuine work of art is very different to an entertainment product. This is because the latter has been designed to maximise the income of its producer. As such, the final product inevitably bears the mark of such calculative origins. While the telos of art generates a tendency towards original and challenging works, culture industry products will tend, in the long run, toward repetition of profitable formulae and gratification of the audience.

Likewise, a genuinely ethically autonomous occupation is very different from those occupations our exchange society makes available, in that the latter have been crafted to, or perhaps evolved to, generate profit. Despite its exaggeration, Adorno's remark that "every visit to the cinema leaves me, against all my vigilance, stupider and worse" (2005a: 25), has - as a resistance to the manipulativeness and vacuity of commercial films - a ring of truth about it. Good films are accidental to the machinery of big studio film production and occur only when there happens to be a coincidence of artistic worth and the broader institutional goals of selling tickets and merchandise. Just as the Hollywood film has not been developed with artistic value in mind, management has not been developed to provide meaningful, humane, virtuous roles and activities; rather, both have been developed for and conditioned by one guiding purpose only: maximising the return on capital investment. However, there is an unresolved possibility here: we have conceded that some films are good, but if this is so then our analogy would seem, against the general tenor of Adorno's account of modernity, to allow for good occupations. It is to this possibility that we turn in the following section.

\section{THE POSSIBILITY OF GOOD WORK}

So far we have been concerned with positioning Adorno in the "underexplored role of... business ethicist as an internal social critic" (Wicks, Werhane, Elms, \& Nolan, 2020: 9). However, in this section we adopt a more constructive task: exploring the possibility of good work even within a social world much deserving of criticism. The ethical quality of

work is usually couched in terms of meaningful work, and contributions in this subfield have focused on topics such as virtue and meaningful work (Beadle \& Knight, 2012), meaningful work as a human need (Yeoman, 2014), and meaningful work and human dignity (Sison, Ferrero, \& Guitián, 2016), amongst others.

Adorno would be suspicious of the optimistic tone of much of this literature, and his remarks in praise of the ideal of "freedom from work" (Adorno \& Horkheimer, 201914: 16) might suggest he inclines towards the anti-work tradition (e.g. Gorz, 1985; Fleming, 2015). Indeed, his privileging of the idea of "eternal peace" (Adorno, 2005a: 157), the notion that "the true society will grow tired of development and, out of freedom, leave possibilities unused," as against the "wishful image of an uninhibited, vital, creative man... the conception of unfettered activity, activity of uninterrupted procreation, of chubby

14 A record of conversations which took place in 1956. 
insatiability, of freedom as frantic bustle," (Adorno, 2005a: 156) lend support to this view. However, Adorno's claim that "free time is shackled to its contrary," (Adorno, 2005b: 167) as well as his disparaging remarks on hobbies (see Adorno, 2005b: 168, 170), implies that good work - work that is autonomous and meaningful - rather than the more passive concept of 'free time', is central to any attempt to live 'less wrongly'. 15

To be sure, modern work is, for Adorno, generally neither free nor meaningful. It is typically directed to an alien end in that it is directed to a purpose that is not one's own. It involves the necessary "subordination of one's activity to the arbitrary will of others" (Hegel, 1991: s.197, emphasis added). And the form of work in exchange society is systematically alien to the individual as well. The character of work, as well as the purpose to which it is put, is determined by profitability and thus efficiency, and this drives the increasing division of labour to separate and specialise functions within the production process so as to whittle away both any sense of purposeful activity toward even an alien end, and any place for the skilful or artful deployment of creative capacities. As Hegel observed, "the specialization and limitation of particular work... leads to an inability to feel and enjoy the wider freedoms, and particularly the spiritual advantages, of civil society." (Hegel, 1991: s.243, original emphasis)

Hegel's remarks here might call to mind Dawkins's (2019) distinction between voluntary employment and coerced servitude. However, as we noted earlier, Adorno's conception of heteronomy is wider, offering grounds to resist equating voluntariness with genuine autonomy. On his view, the autonomy/heteronomy distinction cannot be reducible to the voluntary/coerced distinction, because the latter is derivative of the former. Any plausible account of what distinguishes a voluntary agreement from a coerced one will have to appeal to a theory of autonomy and heteronomy. That is to say, whether any particular sort of agreement is coerced or consensual must depend not on whether the end comes from within the agent or from an external source but on the quality of the relationship between the 'externally' offered motive and the person's nature as an agent.

Autonomy is, for Adorno, an objective, not merely a subjective, quality of a person's relation to his or her activity. It pertains not merely to how the person experiences his or her relation to his or her activity (whether the person voluntarily agrees to or resists it, say), but to the objective quality of that relation, about which the person may be mistaken. As the problems of role-identification imply, a person's endorsing a first-order or higher-order end may be no more than an unconscious rationalisation of the fact that they have no alternative to adopting it. It is not, though, that taking up another's end is necessarily alien that makes modern work heteronomous - taking up another's end can be a supremely autonomous act, as in the endeavours of care involved in parenthood and loving devotion

15 There is some affinity here with Arendt's (1958) distinction between work, labour, and action insofar as both Adorno and Arendt see tedious, heteronomous work as being central to contemporary society and meaningful, autonomous action as being most worthy of our aspirations. See Reeves (2009b) for a discussion of Adorno's relationship to Arendt. 
to others generally. It is, rather, that the market economy blocks the autonomous taking up of another's end as one's own end that makes it heteronomous.

Because of the pervasiveness, as Adorno sees it, of heteronomous ends within employment, the ends pursued in the workplace tend to be divorced from matters of abiding concern and interest to employees, and work tends toward oppressive drudgery. One of the most essential symptoms of the heteronomy of modern work is thus, Adorno suggests, boredom:

Boredom is a function of life under the compulsion to work and under the rigorous division of labour. Boredom need not necessarily exist... Boredom is the reflex reaction to objective dullness... [it] is objective desperation. (2005b: 171)

Here Adorno presents boredom as a mode of suffering, the mode most objectively appropriate to the experience of modern work.

However, there is greater scope to tease out an understanding of good work from Adorno's writings than it might seem. That work is a central determinant of our well-being (as the contemporary business ethics literature would have it) or of our ailing (as Adorno would see it) has been a feature of critical social thought since at least Marx's Economic and Philosophic Manuscripts (Marx, 1978; see also, for discussions of Marx in the business ethics literature, Shaw, 2009; Sinnicks, 2020). Indeed, Aristotle's sharp distinction between praxis and poesis shows that the recognition that human flourishing is enabled or constrained by the activities which shape our lives has been a feature of Western philosophy throughout its history, though perhaps one that has come into and gone out of focus at different times. While Adorno is less willing to make positive claims about human needs and the conditions of flourishing than either Marx or Aristotle, his observations of the suffering that bad work creates - in particular, boredom construed as an appropriate reaction to objective dullness - negatively suggests that he recognises a real human need, suppressed in modern work, for "activities [which] are reasonable and meaningful in themselves" (Adorno, 2005b: 171).

Indeed, while Adorno's pessimism about social life is a prominent feature of his thought, this should not blind us to the fact that this is "coupled with a strong optimism about human potential" (Freyenhagen, 2013: 1). As Adorno puts it, "without exception, men have yet to become themselves. By the concept of the self we should properly mean their potential, and this potential stands in polemical opposition to the [current] reality of the self." (1973a: 278) It is this optimism that grounds Adorno's negative evaluation of modern social life: it is inadequate and unbefitting of humanity, given what we really are and could in actuality become. Without this latent optimism, the pessimistic remarks about our culture, and the overwhelmingly negative evaluations of the wide array of phenomena Adorno discusses, would scarcely be intelligible.

While most work under capitalism is bound to reflect the various pathologies, to greater or lesser degrees, that we have described, there are nevertheless forms of activity which are, again to greater or lesser degrees, distinct from the mundane and alienated realities of work under capitalism. Such activities are marked not only by the individual's opportunity to 
"seek out and arrange his work according to his own intentions" (Adorno, 2005b: 169) but by the objectively meaningful nature of the activities themselves. After all, many who do have the opportunity to choose their own work opt to continue in work that is characterised by the alienation and reification of the exchange principle (think of stereotypical media moguls, workaholic CEOs or corporate tycoons).

Forms of genuine activity are marked by their relative freedom from the reifying forces of exchange society, whereby they approximate kinds of genuine experience that comes close to fulfilling genuine needs for creative activity and granting genuinely autonomous experience, even if the wider context ensures that they will fall some way short of this telos. The best exemplars of such work, for Adorno, are pursuits such as rational enquiry, epitomised by philosophy when in good order, and artistic creation, so these are the most apt focus for an Adornian account of good work.

To be sure, Adorno's appraisal of what has historically become of the practice of philosophy is characteristically negative and mournful. The philosophical tradition has, under the social pressures of the identitarian reification of thinking, largely collapsed into resignation and abdication of its proper telos: in particular, under the "general tendency toward specialization, philosophy too has established itself as a specialized discipline, one purified of all specific content." (Adorno, 2005 $\mathrm{d}^{16}: 6$ ). And because "the domain of every kind of knowledge has been confiscated by the specialized disciplines... philosophical thought feels terrorized and fears being refuted as dilettantism whenever it takes on specific content." (Adorno, 2005d: 7) The consequence is that "the philosophical tradition... today lies in ruins." (2005d: 7) In particular, in both the two main movements of Adorno's time - positivism and Heideggerian fundamental ontology - "thinking becomes a necessary evil and is broadly discredited." (Adorno, 2005d: 9)

Yet the problem with these movements is their abdication of the proper philosophical task, which remains valid: "Thinking loses its element of independence. The autonomy of reason vanishes" (Adorno, 2005d: 9, emphasis added). So this diagnosis of the disintegration of the philosophical enterprise itself testifies to the context-transcendent vitality of the real telos of philosophy that in principle raises it above reification: "philosophy has denied its own constitutive concept: intellectual freedom that does not obey the dictates of specialized knowledge" (Adorno, 2005d: 6) - but in that case philosophy in principle exemplifies just this intellectual freedom that raises it above bad work. And insofar as philosophical activity takes seriously the need to critically resist the evil of the social world, it remains possible:

Philosophy that satisfies its own intention, that does not childishly skip behind its own history and the real one, has its lifeblood in the resistance against the common practices of today and what they serve, against the justification of what happens to be the case (Adorno, 2005d: 6).

That is, philosophy is in principle, in its own concept, an activity that is oriented to genuine, non-reified and non-instrumental experience.

16 In Critical Models, originally published 1969. 
Similarly, despite its contamination by exchange society and subsumption by the culture industry, when practiced genuinely art can, thinks Adorno, "offer both utopian vision and social critique" (Zuidervaart, 2007: 10). Indeed, for Adorno, "both rational inquiry and art, accomplished properly, share features from each other" (Hulatt, 2016: xii). Genuine artworks, for Adorno, have the ethical potential to lift us out of the stupefying context of exchange relations by embodying a non-defensive reconciliation of reason and nature. As he writes regarding Beethoven, "it is only in experiencing its own naturalness that genius soars above nature" (Adorno, 1973a: 397).

Thus, philosophical and artistic activity are something like paradigms of good work - that is, work befitting our human potential. Insofar as our lives are shaped by such activities, and activities that approximate them, this enables us to live less wrongly. It is not that full flourishing, in the Aristotelian sense, is available to us in capitalist society so long as we are artists or philosophers. Neither art nor philosophy can entirely transcend the damaged, unfree, and false conditions in which it exists. It is rather that such activities contain a germ of humanity that is inherently resistant to the modern order and the identity thinking which characterises it.

Creative activities like art and philosophy are relatively - though clearly not absolutely immune to the relentless pressure to be productive and useful at all times, even where the ends to which such production and utility are devoted remain beyond our grasp. In a rare moment of candour about his vision of a better society, Adorno claims that

satisfied need will make it possible to relate to the world without knocking it into shape through universal usefulness. If classless society promises the end of art by sublating the tension between the actual and the possible, then at the same time it also promises the beginning of art, the useless, whose intuition tends towards reconciliation with nature because it is no longer in the service of usefulness to the exploiters. (Adorno, 2017 $\mathrm{b}^{17}: 104$ )

The best art produced in the wrong life allows us, however inadequately, to apprehend the possibilities beyond it and, in a better life, would, perhaps, allow us to move beyond instrumental reason altogether. What we may regard as good work thus does not directly contribute to a 'well lived life', as that possibility is not open to us, according to Adorno. Rather it gives us grounds for thinking that such a life is not impossible entirely. It is individuals' needs for enriching and extending forms of activity that are decisive, and exchange society - which sees every person's labour as no more than a quantity of a fungible stuff - is constitutionally incapable of satisfying them. Creative work of various kinds, by contrast, is in tension with this tendency. Something approximating such autonomous, creative activity is not entirely absent in our social world, but that it is a luxury available to a few rather than something every person is entitled to enjoy is one of the fundamental travesties of wrong life.

17 Originally presented as a seminar in 1942 . The original translation retains several German terms in brackets, which we have removed for the sake of readability. 
This may provide some comfort to artists and scholars, but what of the more prosaic forms of work that make up the overwhelming majority of jobs in our society? Some kinds of work in the contemporary business world are, by these lights, so essentially corrupt that they cannot even be made less bad in any meaningful sense, while others are less radically compromised and can be ameliorated. The key point, however, is that whether or not a kind of work can be ameliorated, to the extent that it can, any ameliorative changes will be in conflict with the fundamental identitarian logic of capitalist society. Such attempts at amelioration will thus be against the grain of the fundamental tendency that exerts its pressure on all aspects of work today.

Nevertheless, sometimes amelioration is, surely, possible. There are bound to be exceptions to the general tendency, but, like the example of good Hollywood films noted earlier, they will be felicitous coincidences. Occasionally, an ameliorative change may happen to be compatible with the drive to maximise profit, but only contingently. Thus, any kind of widespread, significant, and lasting improvement to the world of work would require a transformation of our 'wrong life'. This is because the identitarian logic of exchange that governs economic life in capitalist society, expressed in the overriding importance of the profit motive, makes exchange-value the sole and overriding end of economic activity. Other ends - such as free and meaningful human activity - can show up as ends only when and insofar as they contingently align with the profit motive, which is to say that they never really get to show up as ends at all.

\section{CONCLUDING REMARKS}

We hope to have shown that Adorno's work is, perhaps surprisingly, well placed to contribute to the conversation on the ethical quality of work within the field of business ethics. This is not because Adorno's work can guide us with regard to the quandaries that emerge from engaging in the moral contours of business life but because Adorno's social criticism operates at the level of the social whole. His ethical critique of our social world engages the multitude of factors - metaphysical, economic, psychological, sociological, political, and so on - that shape the realities of work and commercial life and provide the background conditions for any intelligible business ethics, challenging the framing assumptions of many positions and disputes in the discipline. Adorno's critique appraises modern work from the unrestricted standpoint of the potential for human flourishing, eviscerating the suppression of that potential in our social world. And his concretely utopian suggestions on the possibility of good work proceed negatively, through the suffering and frustration wrought by work in our existing social world, to the articulation of forms of genuine, meaningful and liberated human activity possessed of transcendent worth.

Now, insofar as we have been able to show that Adorno's analyses illuminate particular phenomena and problems related to modern work, we will also have provided further support for the overall justification of Adorno's ethics, for the justification of his position 
is ultimately dependent on its capacity to illuminate the concrete phenomena. So, while business ethics can learn from Adorno's insights, that this is the case in turn corroborates the explanatory and elucidatory power of Adorno's Critical Theory.

While it has its own ideological blind spots and biases, like any academic discipline, in light of the Adornian interventions we have outlined, it may be - again, surprisingly - that business ethics has an advantage over more detached forms of ethical theorising in virtue of its potential to capture what is wrong with our current form of ethical life. Its problems are more clearly related to the ethical experience of most people - work and employment, the market society, management, and other such topics covered by the field of business ethics, are central to all of our lives for good or, as is more likely, ill. This suggests that contrary to first impressions, Adorno's contributions to business ethics are illuminating not only from the standpoint of business ethics, but from the standpoint of Critical Theory as well. $^{18}$

\section{References}

Abend, G. 2013. The origins of business ethics in American universities, 1902-1936. Business Ethics Quarterly, 23(2): 171-205.

Abend, G. 2014. The moral background: An inquiry into the history of business ethics. Princeton, NJ: Princeton University Press.

Adorno, T. W. 1973a. Negative dialectics. New York: Continuum.

Adorno, T. W. 1973b. The concept of sociology. In Frankfurt Institute for Social Research (Ed.), Aspects of sociology: 1-15 London: Heinemann.

Adorno, T. W. 1976. Introduction. In T. W. Adorno, H. Albert, R. Dahrendorf, J. Habermas, H. Pilot, \& K. Popper (Eds.), The positivist dispute in German sociology: 1-67. London: Heinemann.

Adorno, T. W. 1993. Hegel: Three studies. Cambridge: Polity Press.

Adorno, T. W. 2000. Problems of moral philosophy. Cambridge: Polity Press.

Adorno, T. W. 2005a. Minima moralia: Reflections on a damaged life. London: Verso Books.

Adorno, T. W. 2005b. Free time. In H Pickford (Trans.), Critical models: 167-76. New York: Columbia University Press.

Adorno, T. W. 2005c. Note on human science and culture. In H. Pickford (Trans.), Critical models: 37-40. New York: Columbia University Press.

\footnotetext{
${ }^{18}$ We would like to thank handling editor, Prof. Lindsay Thompson, as well as two anonymous reviewers
} for BEQ for comments on previous versions of this article. 
Adorno, T. W. 2005d. Why still philosophy. In H. Pickford (Trans.), Critical models: 5-18. New York: Columbia University Press.

Adorno, T. W. 2006. History and freedom: Lectures 1964-1965. Cambridge: Polity Press.

Adorno, T. W. 2008. Lectures on negative dialectics. Cambridge: Polity Press.

Adorno, T. W. 2017a. An introduction to dialectics. Cambridge: Polity Press.

Adorno, T. W. 2017b. Theses on need (M. Shuster \& I. Macdonald, Trans.). Adorno Studies, 1(1): 101-4.

Adorno, T. W., \& Horkheimer, M. 2019. Towards a new manifesto. London: Verso Books. Anderson, E. 2017. Private government: How employers rule our lives (and why we don 't talk about it). Princeton, NJ: Princeton University Press.

Arendt, H. 1958. The human condition. Chicago: University of Chicago Press.

Audi, R. 2012. Virtue ethics as a resource in business. Business Ethics Quarterly, 22(2): 273-91.

Aylsworth, T. 2020. Autonomy and manipulation: Refining the argument against persuasive advertising. Journal of Business Ethics. DOI:10.1007/s10551-020-04590-6.

Baeza, N. 2015. The normative role of negative affect and bodily experience in Adorno. Constellations, 22(3): 354-68.

Beadle, R., \& Knight, K. 2012. Virtue and meaningful work. Business Ethics Quarterly, 22(2): 433-50.

Benton, T. 1977. Philosophical foundations of the three sociologies. London: Routledge.

Bowie, N. E., \& Werhane, P. H. 2004. Management ethics. Oxford: Blackwell.

Brenkert, G. G. 2019. Mind the gap! The challenges and limits of (global) business ethics. Journal of Business Ethics, 155(4): 917-30.

Carroll, A. B. 2000. Ethical challenges for business in the new millennium: Corporate social responsibility and models of management morality. Business Ethics Quarterly, 10(1): 33-42.

Cook, D. 2001. Adorno, ideology and ideology critique. Philosophy and Social Criticism, 27(1): 1-20.

Cunningham, C. (Ed.). 2013. Social networking and impression management: Selfpresentation in the digital age. New York: Rowman and Littlefield.

Dawkins, C. E. 2019. A normative argument for independent voice and labor unions. Journal of Business Ethics, 155(4): 1153-65. 
Deery, S., Kolar, D., \& Walsh, J. 2019. Can dirty work be satisfying? A mixed method study of workers doing dirty jobs. Work, Employment, and Society, 33(4): 631-47.

Donaldson, T. 2000. Are business managers "professionals"? Business Ethics Quarterly, 10(1): 83-94.

Elster, J. 1983. Sour grapes: Studies in the subversion of rationality. Cambridge: Cambridge University Press.

Fleming, P. 2015. The mythology of work: How capitalism persists despite itself. London: Pluto Press.

Flyverbom, M., Deibert, R., \& Matten, D. 2019. The governance of digital technology, big data, and the internet: New roles and responsibilities for business. Business \& Society, 58(1): 3-19.

Freeman, R. E., \& Newkirk, D. 2009. Business as a human enterprise. In S. Gregg \& J. R. Stoner (Eds.), Rethinking business management: Examining the foundations of business education: 139-43. Princeton, NJ: ISI.

Freyenhagen, F. 2013. Adorno's practical philosophy: Living less wrongly. Cambridge: Cambridge University Press.

Freyenhagen, F. 2018. Critical theory and social pathology. In E. Hammer, A. Honneth, \& P. Gordon (Eds.), Routledge companion to the Frankfurt School: 410-23. Abingdon, UK: Routledge.

Geuss, R. 2005. Suffering and knowledge in Adorno. In Outside ethics: 111-30. Princeton, NJ: Princeton University Press.

Goodman, J., \& Arenas, D. 2015. Engaging ethically: A discourse ethics perspective on social shareholder engagement. Business Ethics Quarterly, 25(2): 163-89.

Gorz, A. 1985. Paths to paradise: On the liberation from work. London: Pluto Press.

Habermas, J. 1987. Theory of communicative action: Vol. 2. Lifeworld and system: A critique of functionalist reason. Boston: Beacon Press.

Harcourt, E. 2018. Containment and "rational health": Moran and psychoanalysis. European Journal of Philosophy, 26(2): 798-813.

Heath, J. 2014. Morality, competition, and the firm. Oxford: Oxford University Press.

Hegel, G. W. F. 1991. Elements of the philosophy of right. Cambridge: Cambridge University Press.

Hempel, C., \& Oppenheim, P. 1948. Studies in the logic of explanation. Philosophy of Science, 12: 135-75. 
Hughes, E. C. 1951. Work and the self. In J. Rohrer \& M. Sherif (Eds.), Social psychology at the crossroads: 313-23. New York: Harper.

Hulatt, O. 2016. Adorno's theory of philosophical and aesthetic truth. New York: Columbia University Press.

Islam, G. 2012. Recognition, reification, and practices of forgetting: Ethical implications of human resource management. Journal of Business Ethics, 111(1): 37-48.

Jager, L. 2003. Adorno: A political biography. New Haven, CT: Yale University Press.

Jeffries, S. 2016. Grand hotel abyss: The lives of the Frankfurt School. New York: Verso Books.

Jeske, D., \& Shultz, K. S. 2016. Using social media content for screening in recruitment and selection: pros and cons. Work, Employment, and Society, 30(3): 535-46.

Jutten, T. 2010. Adorno on Kant, freedom and determinism. European Journal of Philosophy, 20(4): 548-74.

Keat, R. 1981. The politics of social theory: Habermas, Freud and the critique of positivism. Chicago: University of Chicago Press.

Klikauer, T. 2015. Critical management studies and critical theory: A review. Capital and Class, 39(2): 197-220.

Léné, A. 2019. Job satisfaction and bad jobs: Why are cleaners so happy at work? Work, Employment, and Society, 33(4): 666-81.

Lippke, R. L. 1999. The "Necessary Evil" Defense of Manipulative Advertising. Business \& Professional Ethics Journal, 18(1): 3-20.

MacIntyre, A. 2007. After virtue (3rd ed.). London: Duckworth.

Marcoux, A. 2009. Business-focused business ethics. In J. Smith (Ed.), Normative theory and business ethics: 17-34. Lanham, MD: Rowman and Littlefield.

Marx, K. 1978. Economic and philosophic manuscripts of 1844, in R. C. Tucker (Ed.), The Marx-Engels reader (2nd ed.): 66-125. New York: W. W. Norton.

Melé, D. 2001. Loyalty in business: Subversive doctrine or real need? Business Ethics Quarterly, 11(1): 11-26.

Moore, G. 2008. Re-imagining the morality of management: A modern virtue ethics approach. Business Ethics Quarterly, 18(4): 483-511.

Muller-Doohm, S. 2003. Adorno. Cambridge: Polity.

Munro, I., \& Thanem, T. 2018. The ethics of affective leadership: Organizing good encounters without leaders. Business Ethics Quarterly, 28(1): 51-69. 
Musílek, K., Jamie, K., \& McKie, L. 2020. Cold winds and warm attachments: Interrogating the personal attachment to neoliberal work and economy. Work, Employment, and Society, 34(3): 514-25.

Neurath, O. 1973. Empirical sociology. In R. Cohen \& M. Neurath (Eds.), Empiricism and sociology: 319-421. Dordrecht, Netherlands: D. Reidel.

Nevasto, J. 2019. The concept of need in the thought of Theodor Adorno. Unpublished doctoral thesis, University of Essex.

Nussbaum, M. 2001. Adaptive preferences and women's options. Economics and Philosophy, 17(1): 67-88.

O'Connor, B. 2004. Adorno's negative dialectic: Philosophy and the possibility of critical rationality. Cambridge, MA: MIT Press.

Outhwaite, W. 1987. New philosophies of social science. Basingstoke, UK: Macmillan.

Parker, M. 2003. Business, ethics and business ethics: Critical theory and negative dialectics. In M. Alvesson \& H. Willmott (Eds.), Studying management critically: 197219. Thousand Oaks, CA: Sage.

Popper, K. 2002. The logic of scientific discovery. London: Routledge.

Raz, J. 1986. The morality of freedom. Oxford: Oxford University Press.

Reeves, C. 2009a. Causality and critical theory. Journal of Critical Realism, 8(3): 316-42.

Reeves, C. 2009b. "Exploding the limits of the law": Judgement and freedom in Arendt and Adorno. Res Publica, 15(2): 137-64.

Reeves, C. 2016a. Adorno, freedom and criminal law. Law and Critique, 27(3): 323-48.

Reeves, C. 2016b. Beyond the postmetaphysical turn: Ethics and metaphysics in critical theory. Journal of Critical Realism, 15(3): 217-44.

Root, T., \& McKay, S. 2014. Student awareness of the use of social media screening by prospective employers. Journal of Education for Business, 89: 202-6.

Rubery, J., Grimshaw, D., Keizer, A., \& Johnson, M. 2018. Challenges and contradictions in the "normalising" of precarious work. Work, Employment, and Society, 32(3): 509-27.

Satz, D. 2010. Why some things should not be for sale: The moral limits of markets. Oxford: Oxford University Press.

Sayer, A. 1992. Method in social science. London: Routledge.

Scherer, A. G. 2015. Can hypernorms be justified? Insights from a discourse-ethical perspective. Business Ethics Quarterly, 25(4): 489-516. 
Scherer, A. G., \& Palazzo, G. 2007. Toward a political conception of corporate responsibility: Business and society seen from a Habermasian perspective. Academy of Management Review, 32(4): 1096-1120.

Shaw, W. H. 2009. Marxism, business ethics, and corporate social responsibility. Journal of Business Ethics, 84(4): 565-76.

Sinnicks, M. 2018. Leadership after virtue: Macintyre's critique of management reconsidered. Journal of Business Ethics, 147(4): 735-46.

Sinnicks, M. 2020. "We ought to eat in order to work, not vice versa": MacIntyre, practices, and the best work for humankind. Journal of Business Ethics. DOI:10.1007/s10551-02004603-4.

Sison, A. J. G., Ferrero, I., \& Guitián, G. 2016. Human dignity and the dignity of work: Insights from Catholic social teaching. Business Ethics Quarterly, 26(4): 503-28.

Slovensky, R., \& Ross, W. H. 2012. Should human resource managers use social media to screen job applicants? Managerial and legal issues in the USA. info, 14(1): 55-69.

Sternberg, E. 2000. Just business: Business ethics in action (2nd ed.). Oxford: Oxford University Press.

Sykes, G., \& Matza, D. 1957. Techniques of neutralization: A theory of delinquency. American Sociological Review, 22: 664-70.

Tsoukas, H. 2019. Philosophical organization theory. Oxford: Oxford University Press.

Van Iddekinge, C. H., Lanivich, S. E., Roth, P. L., \& Junco, E. 2016. Social media for selection? Validity and adverse impact potential of a Facebook-based assessment. Journal of Management, 42(7): 1811-35.

Varelius, J. 2009. Is whistle-blowing compatible with employee loyalty? Journal of Business Ethics, 85(2): 263-75.

Visser, M. 2019. Pragmatism, critical theory and business ethics: Converging lines. Journal of Business Ethics, 156(1): 45-57.

von Kriegstein, H. 2016. Professionalism, agency, and market failures. Business Ethics Quarterly, 26(4): 445-64.

Wicks, A. C., Werhane, P. H., Elms, H., \& Nolan, J. 2020. Spheres of influence: A Walzerian approach to business ethics. Journal of Business Ethics. DOI:10.1007/s10551020-04616-z.

Wiggerhaus, R. 1994. The Frankfurt School: Its history, theories and political significance. Cambridge: Polity.

Yeoman, R. 2014. Conceptualising meaningful work as a fundamental human need. Journal of Business Ethics, 125(2): 235-51. 
Zuidervaart, L. 1991. Adorno's aesthetic theory: The redemption of illusion. Cambridge, MA: MIT Press.

Zuidervaart, L. 2007. Social philosophy after Adorno. Cambridge: Cambridge University Press. 